\title{
In vitro PROPAGATION OF Sprekelia formosissima Herbert., A WILD PLANT WITH ORNAMENTAL POTENTIAL
}

\section{PROPAGACIÓN in vitro DE Sprekelia formosissima Herbert., PLANTA SILVESTRE CON POTENCIAL ORNAMENTAL}

\author{
Marisol Cázarez Prado1, María Andrade Rodríguez ${ }^{2 *}$, Ángel Villegas Monter ${ }^{3}$, Irán Alia Tejacal², \\ Óscar G. Villegas Torres ${ }^{2}$ y Víctor López Martínez ${ }^{2}$
}

${ }^{1}$ Carrera de Ingeniería Hortícola y ${ }^{2}$ Facultad de Ciencias Agropecuarias, Universidad Autónoma del Estado de Morelos. Av. Universidad 1001. 62209, Cuernavaca. Morelos. Tel. 01 (777) 329-7046. ${ }^{3}$ Postgrado de Recursos Genéticos y Productividad-Fruticultura, Colegio de Postgraduados-Campus Montecillo. Km 36.5 Carr. México-Texcoco. 56230, Montecillo, Texcoco, Edo. de México.

* Corresponding author (andradem65@hotmail.com)

\section{SUMMARY}

Vegetative propagation of Sprekelia (Sprekelia formosissima Herbert.) in natural conditions is limited because it produces only one bulb per year or none. The objective of this research was to generate an in vitro propagation protocol for this species to increase its commercial propagation rate without extracting the species from its natural habitat. Bulbs of 4 to $5 \mathrm{~cm}$ in diameter were used as disinfested donor explant material; $1 \mathrm{~cm}^{2}$ explants were obtained from the cataphyll leaves with and without a portion of basal disc; these explants were established in MS medium supplemented with $8.87 \mu \mathrm{M}$ of $\mathrm{N}^{6}$ benzyl adenine (BA) and $0.98 \mu \mathrm{M}$ of indole-3- butyric acid (IBA). For shoot multiplication, bulblets obtained from the previous phase were used as explants and cultivated in MS medium with $2.5,5,10,15$ and $20 \mu \mathrm{M}$ of BA combined with IBA at a 10:1 ratio (BA: IBA). Shoots obtained from multiplication were established in MS medium supplemented with 1, 2, 3, 4, and $5 \%$ $(w / v)$ sucrose to promote growth. Bulblets were rooted in MS medium supplemented with $0,0.49,0.98,1.96,3.93$ and $7.8 \mu \mathrm{M}$ of IBA. Once roots formed, they were transferred to soil to assess their acclimation. We obtained $89.1 \%$ of aseptic explants, of which $86 \%$ formed two shoots on the average. Multiplication of shoots increased as BA concentration increased in culture medium, and the best results $(75 \%$ of bulblets with shoots, 2.66 shoots per bulblet and $2.0 \mathrm{~mm}$ diameter shoots) were obtained with $20 \mu \mathrm{M}$ BA. The best bulb growth in diameter $(4.2 \mathrm{~mm})$ and number of bulblet leaves (3.5) was obtained with $5 \%$ sucrose. The use of $0.98 \mu \mathrm{M}$ IBA resulted in greater rooting percentage (93.7) and number of roots per bulblet (2.0), which were $2.4 \mathrm{~cm}$ long on average. Up to $83 \%$ of the bulblets survived acclimation. This protocol to micropropagate Sprekelia formosissima allowed the production of at least 96 bulblets from one mother bulb in a six months period of in vitro culture.

Index words: Sprekelia formosissima, micropropagation, bulblet multiplication.

\section{RESUMEN}

La propagación vegetativa de Sprekelia (Sprekelia formosissima Herbert.) en condiciones naturales es limitada. Esta produce sólo un bulbo por año o ninguno, por lo que el objetivo de esta investigación fue generar un protocolo de propagación in vitro para incrementar el número de plantas de esta especie y poder propagarla comercialmente sin extraerla de su hábitat natural. Se usaron bulbos de 4 a $5 \mathrm{~cm}$ de diámetro como material donador de explantes, se desinfestaron y se obtuvieron explantes de $1 \mathrm{~cm}^{2}$ a partir de los catáfilos con y sin disco basal. Los explantes se establecieron en medio MS con $8.87 \mu \mathrm{M}$ de $\mathbf{N}^{6}$ bencil adenina (BA) y $0.98 \mu \mathrm{M}$ de ácido 3- indolbutírico (AIB). Para su multiplicación in vitro, se usaron los bulbillos obtenidos en la fase anterior y se cultivaron en medio MS con 2.5, 5, 10, 15 y $20 \mu \mathrm{M}$ de BA en combinación con AIB en proporción 10:1(BA:AIB). Para inducir el crecimiento de brotes, los bulbillos se establecieron en medio MS suplementado con $1,2,3,4$, y $5 \%$ de sacarosa. Los bulbillos se enraizaron en el medio MS suplementado con $0,0.49,0.98,1.96,3.93$ y 7.8 $\mu \mathrm{M}$ de AIB y una vez enraizados se trasplantaron a suelo para evaluar su aclimatación. Se obtuvo $89.1 \%$ de explantes asépticos, de los cuales $86 \%$ formaron dos brotes en promedio. La multiplicación de brotes aumentó conforme se incrementó la cantidad de BA en el medio de cultivo, y la dosis optima fue $20 \mu \mathrm{M}$ (75 \% de bulbillos con brotes, 2.66 brotes por bulbillo y $2.0 \mathrm{~cm}$ de diámetro de brotes). El mejor crecimiento en diámetro y número de hojas de los brotes se obtuvo con 5 $\%$ de sacarosa. El uso de $0.98 \mu \mathrm{M}$ de AIB indujo el mayor porcentaje de enraizamiento (93.7), y número de raíces por bulbo (2.0) de $2.4 \mathrm{~cm}$ de longitud en promedio, en comparación con los otros tratamientos. Durante la aclimatación sobrevivieron $83 \%$ de los bulbillos. El protocolo establecido para micropropagar Sprekelia formosissima permite la producción de al menos 96 bulbillos a partir de un bulbo madre, en seis meses de cultivo in vitro.

Palabras clave: Sprekelia formosissima, micropropagación, multiplicación de bulbillos.

\section{INTRODUCTION}

Sprekelia formosissima Herbert. is one of the most beautiful ornamental bulb plants of México, and has generated a great interest in the past (Leszczyñska-Borys et al., 1995). It is a wild herbaceous plant of the Amaryllidaceae family, of a Mexican monotypic genus (Sánchez, 1979). It was originally considered to be endemic 
only to México (Sánchez, 1979), but later Van Dijk and Kupershoek (2003) and López-Ferrari and Espejo-Serna (2002) showed that it originated both in México and Guatemala. This species is widely distributed throughout most of the national territory, including the mountainous areas of Chiapas, Chihuahua, Distrito Federal, Durango, Guerrero, Guanajuato, Hidalgo, Jalisco, State of México, Michoacán, Morelos, Oaxaca, Puebla, Querétaro and Veracruz (López-Ferrari and Espejo-Serna, 2002). Its scarlet red color and the form of its flowers confer upon it potential for ornamental use. It can be grown for cut flowers, potting, yards and homes (Leszczyñska-Borys and Borys, 2001). In México, it is rarely used in garden design, although it has been used for medicinal purposes since the bulb contains saponins which are supposedly useful for controlling hair loss (Sánchez, 1979).

There is a current trend of using wild plants for ornamental purposes, but this comes with a downside as numerous species are being lost as a result of illegal marketing of plants and their products, which are extracted from their natural environment and then sold in foreign and local markets (Chimal and Corona, 2003). It is necessary then to search for efficient propagation methods of wild species of economic interest to prevent their extinction.

According to Leszczyñska-Borys and Borys (2000), the seeds from Sprekelia are highly viable for up to one year after harvest, followed by a rapid decrease in viability. This characteristic and an initial fast germination are considered to be an adaptation to a short and intense rainy period. From the phytogenetic resource conservation point of view, propagation by seeds is the most adequate way of multiplication.

Natural asexual propagation of bulbous plants is based on the production of bulblets or offspring. This method is slow because the process requires approximately 4 to 5 years from the start of bulb formation to flowering (Hartmann et al., 1990). Another vegetative propagation method is based on the use of bulb stakes (Hartmann et al., 1990), which allows production of a greater number of bulblets per bulb, although the time required for flower initiation is similar to that of the offspring method.

Vegetative propagation of Sprekelia under natural conditions is limited as it only produces a single offspring per year, or none. Therefore, it is important to devise another propagation method for increasing the number of plants obtained in commercial production systems. In vitro culture techniques could be an alternative to multiplying this species and preventing over-harvesting of their bulbs from natural populations. Nevertheless, there is no background information available on this way of propagating Sprekelia.
The objective of this study was to generate an in vitro propagation protocol for multiplying $S$. formosissima plants.

\section{MATERIALS AND METHODS}

\section{Plant material}

The research was carried out from August 2006 to July 2007. Bulbs of 4 to $5 \mathrm{~cm}$ in diameter from adult Sprekelia plants were used as donor explant material. They were collected at natural vegetation areas in Cuernavaca, Morelos (Figure 1) at an altitude of $1900 \mathrm{~m}$. The climate in this region is semi-warm-sub-humid with intense rainfall in Summer and lower precipitation in Winter; year-round temperatures range from 9 to $32{ }^{\circ} \mathrm{C}$, and the average annual rainfall is $1500 \mathrm{~mm}$ (García, 1988).

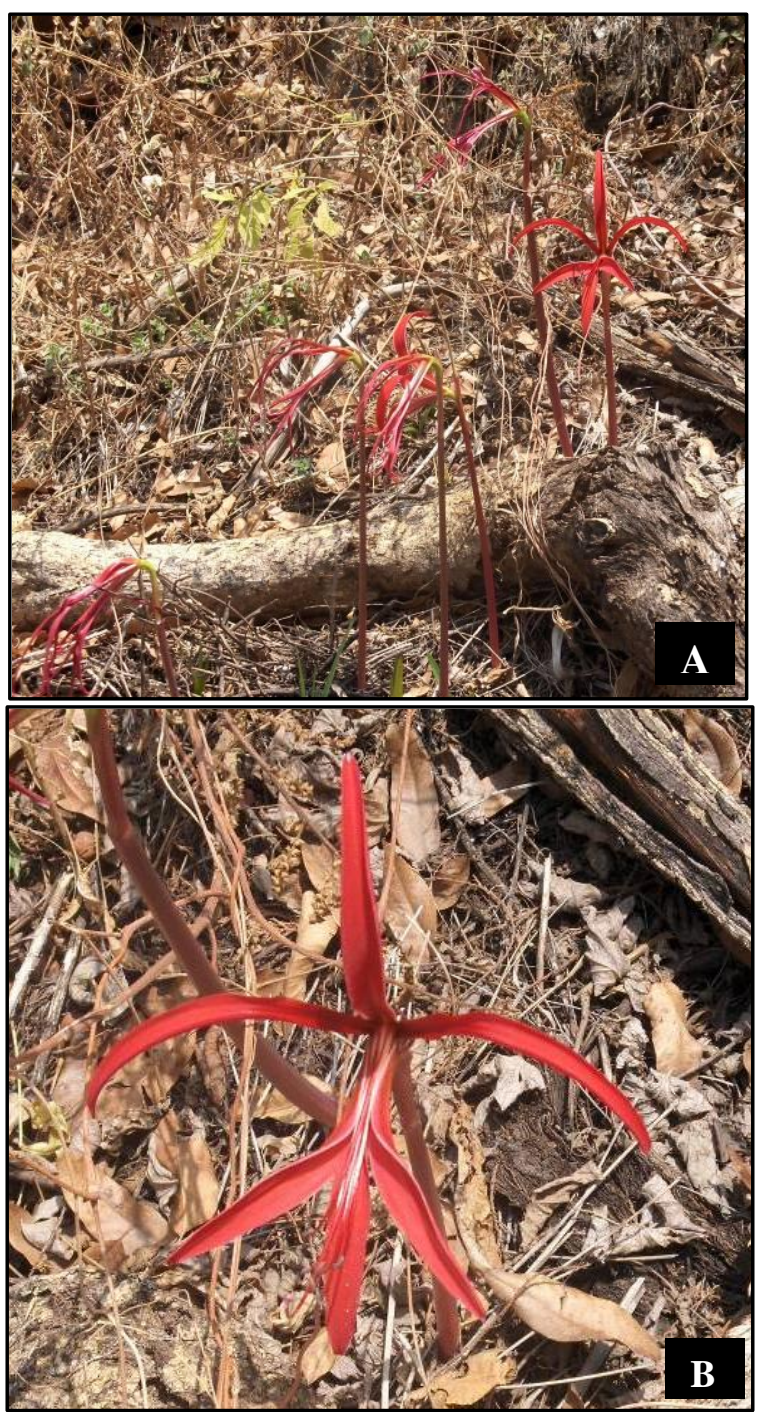

Figure 1. Adult Sprekelia plants located in the natural vegetation areas of the Universidad Autónoma del Estado de Morelos, México. A) An overview of several blooming plants; B) A close-up of a single blooming plant. 


\section{In vitro aseptic culture and shoot induction}

The basal Murashigue and Skoog (1962) medium (MS) prepared with deionized water was supplemented (in $\mathrm{mg} \mathrm{L}^{-1}$ ) with $\mathrm{NaH}_{2} \mathrm{PO}_{4}$ (0.170), inositol (100), thiamine (0.4), pyridoxine (1.0), niacin (1.0), glycine (0.4), and adenine sulphate (80), as well as with 6-bencil adenine (BA) 8.87 $\mu \mathrm{M}$, 3-indolbutyric acid (IBA) $0.98 \mu \mathrm{M}$ and sucrose (3\%, $\mathrm{w} / \mathrm{v})$; agar $(0.8 \%, \mathrm{w} / \mathrm{v})$ was used as gelifying agent in this experiment. The medium $\mathrm{pH}$ was adjusted to 5.7 before adding the agar; once agar was dissolved, it was distributed in aliquots of $20 \mathrm{~mL}$ in culture jars of $100 \mathrm{~mL}$.

For the aseptic culture of explants, bulbs were cleaned of roots and external dry scales eliminated until white and turgid scales appeared (Figure 2A). Clean bulbs were washed with commercial antibacterial soap for $10 \mathrm{~min}$, stirred for $15 \mathrm{~min}$ in a fungicide/bactericide solution $\left(\right.$ Captan ${ }^{\circledR}+$ Gowan $\AA$, each at $\left.0.5 \mathrm{~g} \mathrm{~L}^{-1}\right)$, rinsed in sterile water, placed in ethanol $(70 \%, \mathrm{v} / \mathrm{v})$ for $1 \mathrm{~min}$, rinsed once more and finally immersed in a sodium hypochlorite solution $(\mathrm{NaOCl} 1.8 \%, \mathrm{v} / \mathrm{v})$ for $5 \mathrm{~min}$ for disinfection. Then they were rinsed three times with sterile water.

To obtain the explants, the bulbs were sectioned in the middle and the basal scales were divided into $1 \mathrm{~cm}^{2}$ explants, ensuring that they included a portion of basal stem; in addition, portions without the basal disc were also used. For shoot induction, four explants were used per culture jar, for a total of 50 jars. After one week of in vitro culture, contamination percentages were recorded; the number of explants with shoots, shoots per explant and number of leaves per shoot were evaluated after six weeks of in vitro culture.

\section{Shoot multiplication}

Shoots obtained in the induction stage were used for multiplication. They were grown in MS medium supplemented (in mg L ${ }^{-1}$ ) with inositol (100), thiamine (0.4), pyridoxine (1.0), niacin (1.0), glycine (0.4) and adenine sulphate (80), plus sucrose $3 \%(\mathrm{w} / \mathrm{v})$, and agar $0.7 \%$ $(w / v)$. Five concentrations of BA $(2.5,5,10,15$, and 20 $\mu \mathrm{M})$ each combined with IBA at a 10 to 1 ratio (BA/AIB) were tested; $\mathrm{pH}$ was adjusted to 5.7. The media was distributed in $20 \mathrm{~mL}$ aliquots in culture jars of $200 \mathrm{~mL}$. Three bulblets without roots and dead tissue parts were established in each jar. Each leaf was sheared to only $1 \mathrm{~cm}$ in length.

A completely randomized design with five replications per treatment was used for statistical analysis, considering one culture jar as experimental unit. The percentage of bulblets with shoots, number of shoots per bulblet and shoot diameter were measured six weeks after planting.

\section{Bulblet growth}

Bulblet growth was promoted using MS medium supplemented (in $\mathrm{mg} \mathrm{L}^{-1}$ ) with inositol (100), thiamine (0.4), pyridoxine (1.0), niacin (1.0) and glycine (0.4). No BA or IBA were used in this stage. Five sucrose concentrations were tested in the media $(1,2,3,4$, and $5 \%, w / v)$. Agar $(0.7 \%, w / v)$ was added and the medium and $\mathrm{pH}$ was adjusted to 5.7. Then the medium was distributed in $40 \mathrm{~mL}$ aliquots in culture jars. Three bulblets were placed in each culture jar.

This experiment was established under a completely randomized experimental design with three replications per treatment (three culture jars). Assessment was carried out for five weeks, taking into account the bulblet diameter and the number of leaves per bulblet.

\section{Bulblet root formation}

For rooting, the MS medium supplemented with inositol (100 mg L $\left.{ }^{-1}\right)$, thiamine $\left(0.4 \mathrm{mg} \mathrm{L}^{-1}\right)$, pyridoxine $\left(1.0 \mathrm{mg} \mathrm{L}^{-1}\right)$, niacin $\left(1.0 \mathrm{mg} \mathrm{L}^{-1}\right)$, glycine $\left(0.4 \mathrm{mg} \mathrm{L}^{-1}\right)$ and sucrose $(3 \%$, $\mathrm{w} / \mathrm{v})$ was used. Six concentrations of IBA were tested $(0$, $0.49,0.98,1.96,3.93$ and $7.8 \mu \mathrm{M})$. Agar $(0.7 \%, \mathrm{w} / \mathrm{v})$ was added and the $\mathrm{pH}$ was adjusted to 5.7. The medium was distributed in $20 \mathrm{~mL}$ aliquots in culture jars of $200 \mathrm{~mL}$.

A completely randomized experimental design was used with three replications per treatment considering one culture jar as one experimental unit. Three bulblets were placed in each culture jar, and two weeks later the percentage of bulblets with roots, roots per bulblet and root length were evaluated.

In each of these research experiments, the culture media were sterilized at $121{ }^{\circ} \mathrm{C}$ for $20 \mathrm{~min}$. Incubation conditions were 16 hours light, 24 to $26^{\circ} \mathrm{C}$ ambient temperature and $32.5 \mu \mathrm{mol}$ photons $\mathrm{m}^{-2} \mathrm{~s}^{-1}$ of light intensity.

\section{Statistical analysis}

The recorded data as percent were transformed using the formula: $\mathrm{Y}^{\prime}=\operatorname{arcsine} \mathrm{Y}$, where $\mathrm{Y}$ is the variable number in percent. The data processing was done by SAS (SAS Institute, 1998). Effect of treatments was tested by analysis of variance and differences among means were compared by the Tukey test $(\mathrm{P} \leq 0.05)$.

\section{Acclimation in greenhouse}

Bulblets with well-developed roots were removed from the culture jars, agar was eliminated and the bulblets were washed. 
After that, the bulblets were placed in a fungicide-bactericide solution (Kasumin ${ }^{\circledR}, 3 \mathrm{~mL} \mathrm{~L}^{-1}$ ) and then transferred in $9 \mathrm{~cm}$ diameter plastic pots containing organic soil and agrolite (2:1, $\mathrm{v} / \mathrm{v})$. Then the plants were covered with plastic cups to prevent dehydration and placed in a greenhouse for growth. Plant survival percent was recorded at 7 and 12 weeks.

\section{RESULTS AND DISCUSSION}

\section{In vitro aseptic culture and shoot induction}

In vitro establishment of explants (scales) up to $89.1 \%$ of aseptic cultures was obtained; the contamination (10.9\%) was mostly caused by fungi and to a lesser extent by bacteria. Fungi growth was observed on the surface of the explant and extended quickly throughout the culture jar. Meanwhile, bacteria initiated their growth at the edge of the explants and remained there without invading the culture medium.

This high ratio of axenic explants was achieved since previous experiments were conducted to improve the disinfection methodology. These results are acceptable, considering that such explants came directly from the field, and also because these organs grow in the soil which according to Ziv and Lilien-Kipnis (1997) makes it difficult to obtain a high asepsis percentage. In addition, serious contamination problems frequently occur with field-grown material. Ault (1995) reported that the establishment of bulb scales from Eucomis autumnalis had $90 \%$ contamination rates.

At this stage the explants showed shoot formation two weeks after in vitro establishment. Direct organogenesis process was faster than in other bulb species such as Eucomis autumnalis, E. comosa and E. zambesiaca, which required foor week to reach the same response (Ault, 1995), while Narcissus asturiensis requiered as long as eight weeks (Santos et al., 2002). Shoot formation was observed in explants containing a portion of the bulb basal disk (Figure 2B), while those without it did not develop any shoots and only became swollen. These results agree with reports by Ault (1995) who observed that shoots formed from three species of Eucomis originated from the scale region next to the basal disk.
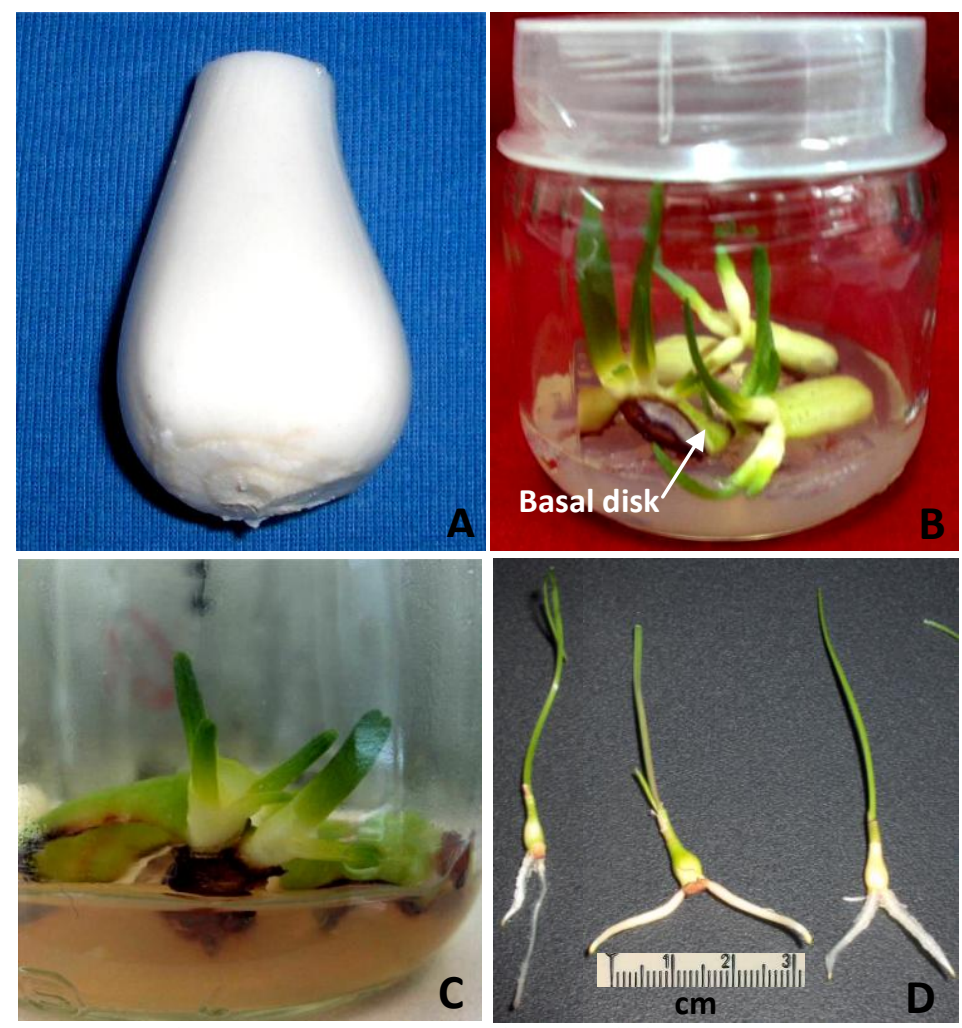

Figure 2. In vitro propagation of Sprekelia formosissima A) Clean bulb used as initial explant; B) Shoot formation (bulblet) from scales during shoot induction (arrow showing the basal disk of the bulb); C) Shoots produced during the multiplication stage showing two to three leaves; D) Rooted bulblets with two or three roots. 
Grootaarts et al. (1981) indicated that at the beginning of in vitro cultivation there are meristems in the axillary part of the bulb scales. Nevertheless, there are also groups of meristematic cells that develop quickly in vitro through mitotic division, until they form meristems in the bulb.

Up to $86 \%$ of the explants developed from one to four shoots, with an average of two shoots, which had two to three leaves (Figure $2 \mathrm{C}$ ). The number of shoots per explant was low, but it was similar to the numbers obtained for other species of bulb plants; for example, 1.0 to 3.7 shoots were obtained in Eucomis autumnalis, 1.0 to 2.9 in E. comosa, and 1.0 to 6.9 in E. zambesica (Ault, 1995). Nonetheless, the number of shoots might be increased by making some modifications to the culture medium.

\section{Shoot multiplication}

New shoot development occurs at the base of explant bulblet meristematic cells (Grootaarts et al., 1981), while mitotic division gives rise to de novo organogenesis of shoot formation. In our study, we observed a significant effect $(\mathrm{P} \leq$ 0.01) of growth regulators concentration on the number of bulblets producing shoots. The percentage of bulblets with shoots increased from 33 to 75 as the BA/IBA concentration increased; the greatest percentage was obtained with $20 \mu \mathrm{M}$ of BA combined with $2 \mu \mathrm{M}$ of IBA (Table 1).

The effect of the concentration of BA/IBA was significant (P $\leq 0.05$ ) on the number of shoots per bulblet, which ranged from 1.12 to 2.66. Increases in BA concentration resulted in increases shoots per bulblet, so that the greatest number of these vegetative structures was obtained with the highest BA/IBA concentration (Table 1).

The results obtained in this study agree with reports by Mohamed-Yasseen (2002), who observed that the number of shoots of Hymenocallis speciosa increased from 0.8 to 3.1 as BA concentration increased from 2.2 to $22.0 \mu \mathrm{M}$. Similarly, Ault (1995) claimed that the number of shoots per explant increased from 2.3 to 3.6 in E. autumnalis and from 1.6 to 6.9 in E. zambesiaca when BA increased from 4.4 to 22.2 $\mu \mathrm{M}$.
The BA/IBA concentration also had a highly significant ( $\mathrm{P}$ $\leq 0.01$ ) effect on the increase of bulblet diameter. Bulblet diameter increased as BA concentration increased, reaching $2.0 \mathrm{~mm}$ when using $20 \mu \mathrm{M}$ of BA and $2 \mu \mathrm{M}$ of IBA.

In most organogenesis research when cytokinin concentration is varied the auxin concentration is kept constant. In this study both BA and IBA concentration varied but maintained a 10 to 1 relationship in favor of cytokines. According to Segura (2000), the differentiation of vegetative buds is promoted by cytokinin/auxin balances that favor cytokinins, as these hormones promote the differentiation of adventitious buds which is determined by the concentration and cell type upon which they act.

\section{Bulblet growth}

Media sucrose concentration had a significant effect $(\mathrm{P} \leq$ 0.01) on Sprekelia bulblet growth, since as its concentration increased the bulblets became larger and produced more leaves. Bulblet diameter varied from 2.9 to $4.2 \mathrm{~mm}$ and leaf number increased from 2.0 to 3.5 with $5 \%$ sucrose, which thus became the best sucrose concentration for growing bulblets (Table 2). Tipirdamaz (2003) reported that the use of 3 to $6 \%$ sucrose had no effect on the growth of Galanthus ikariae bulbs. Nevertheless, Santos et al. (2002) reported that Narcissus asturiensis bulblets increased in diameter after $90 \mathrm{~d}$ in cultivation, reaching up to $8 \mathrm{~mm}$. when $9 \%$ sucrose was used.

Table 2. Effects of sucrose concentration on the growth of Sprekelia formosissima bulblets after five weeks in culture.

\begin{tabular}{lcc}
\hline $\begin{array}{l}\text { Sucrose } \\
(\%, \mathrm{w} / \mathrm{v})\end{array}$ & $\begin{array}{c}\text { Bulblet diameter } \\
(\mathrm{mm})\end{array}$ & $\begin{array}{c}\text { Number of leaves } \\
\text { per bulblet }\end{array}$ \\
\hline 1 & $2.9 \mathrm{c}$ & $2.0 \mathrm{~b}$ \\
2 & $3.0 \mathrm{c}$ & $2.6 \mathrm{ab}$ \\
3 & $3.1 \mathrm{bc}$ & $2.8 \mathrm{ab}$ \\
4 & $3.8 \mathrm{ab}$ & $3.0 \mathrm{a}$ \\
5 & $4.2 \mathrm{a}$ & $3.5 \mathrm{a}$ \\
MSD $(\mathrm{P} \leq 0.05)$ & 0.75 & 0.78 \\
\hline
\end{tabular}

Means in a column with same letter are not statistically different (Tukey, $0.05) ; \mathrm{MSD}=$ minimum significant difference; $\mathrm{n}=18$ bulblets.

Table 1. Effect of $\mathbf{N}^{6}$-benzyladenine/Indol-3- butyric acid (BA/IBA) concentrations on the multiplication of Sprekelia formosissima bulblets after six weeks in culture.

\begin{tabular}{lclclcl}
\hline $\begin{array}{l}\text { BA/IBA } \\
(\mu \mathrm{M})\end{array}$ & $\begin{array}{c}\text { Bulblets with shoots } \\
(\%)\end{array}$ & $\begin{array}{c}\text { Number of shoots } \\
\text { per bulblet }\end{array}$ & $\begin{array}{c}\text { Shoot diameter } \\
(\mathrm{mm})\end{array}$ \\
\hline $2.5 / 0.25$ & 33.0 & $\mathrm{c}$ & 1.12 & $\mathrm{~b}$ & 1.30 & $\mathrm{~b}$ \\
$5 / 0.5$ & 46.5 & $\mathrm{bc}$ & 1.32 & $\mathrm{~b}$ & 1.35 & $\mathrm{~b}$ \\
$10 / 1.0$ & 55.0 & $\mathrm{abc}$ & 1.33 & $\mathrm{~b}$ & 1.41 & $\mathrm{~b}$ \\
$15 / 1.5$ & 66.0 & $\mathrm{ab}$ & 1.34 & $\mathrm{~b}$ & 1.42 & $\mathrm{~b}$ \\
$20 / 2.0$ & 75.0 & $\mathrm{a}$ & 2.66 & $\mathrm{a}$ & 2.00 & $\mathrm{a}$ \\
MSD $(\mathrm{P} \leq 0.05)$ & 27.18 & 1.20 & & 0.39 & \\
\hline
\end{tabular}

Means in a column with same letter are not statistically different (Tukey, 0.05); MSD = minimum significant difference; $\mathrm{n}=25$ bulblets. 
The increase in bulb growth related to sucrose is attributable to a greater availability of carbon structures to produce new cellular components. In this sense, Pierik (1987) stated that growth and development of tissues or organs increases with sugar concentration until it reaches an optimum point after which any additional amount of sugar has no influence on plant morphogenesis.

\section{Bulblet root formation}

Root development was observed 7 d after their establishment in the root formation media, and roots originated from the stem (basal disk). There was a significant effect $(\mathrm{P} \leq 0.01)$ of IBA concentration on root induction and development. The rate of rooted bulblets increased with the use of auxin; nevertheless, at concentrations above $0.98 \mu \mathrm{M}$ root formation decreased. The best response for root formation was found at $0.98 \mu \mathrm{M}$ of IBA, with $93.7 \%$ of rooted bulblets (Table 3). This root formation percentage was high when compared to the $25 \%$ obtained by Tipirdamaz (2003) using $5.3 \mu \mathrm{M}$ of NAA in Galanthus ikariae bulbs, as they considered NAA an important factor for root formation in this species.

One to three roots per bulblet (Figure 2D) were formed, with a gradual increase in the number of roots per bulblet as the medium IBA concentration increased 0 to $1.96 \mu \mathrm{M}$, while higher IBA concentrations caused a lower number of roots per bulblet (Table 3), most likely due to an inhibitory effect (Pierik, 1987).

Root length was also affected by IBA concentration as they were longer and thinner when the hormone was not used. As auxin concentration increased in the culture medium, roots became shorter and thicker than those produced by bulblets grown without this hormone (Table 3 ).

Taking into consideration the percentage of roots, roots per bulblet and root length, the best IBA concentration for rooting was $0.98 \mu \mathrm{M}$. In contrast, bulbs from Scilla siberica had optimum rooting with $0.49 \mu \mathrm{M}$ IBA (Chaudhuri and Sen, 2002), thus suggesting that the effect of auxin concentration varies according to genotype even if they are bulb forming species.

Adequate auxin concentrations induce root formation in isolated tissues, and as its concentration increases so does cell sensitivity (Acosta et al., 2000). Nevertheless, when auxin concentration surpasses the optimum for each species, an inhibitory effect may develop on roots causing formation of calli instead of roots.

\section{Acclimation}

Acclimation of in vitro plantlets is the end of the multiplication process. In this study it was observed that at seven weeks after transplant to soil, $83 \%$ of plants maintained their leaves with which they were established in soil, while the leaves of the remaining $17 \%$ died. Furthermore, $8.8 \%$ of surviving transplanted plants developed new leaves. Nevertheless, at 12 weeks only $63 \%$ of the plants maintained their original leaves, and $73 \%$ of these plants produced new leaves. Likewise, bulblets also formed new roots thus becoming better anchored. Plants generally develop first a root system and thereafter the shoot. Plants that lost their leaves between the first and second readings were found to have live dormant bulblets. The survival rate obtained in this research (83\%) is higher than the $28 \%$ reported by Tipirdamaz (2003) during acclimation of Galanthus ikariae.

The number of shoots obtained from each bulb (96 shoots in 6 months) surpassed the number of offspring that can be obtained under natural conditions ( 1 to 2 bulbs in one year). In addition, these results can be improved with further research.

Table 3. Effect of indole-3-butyric acid (IBA) concentration on rooting of Sprekelia formosissima after two weeks in culture.

\begin{tabular}{lccc}
\hline IBA & $\begin{array}{c}\text { Bulblets with roots } \\
(\mu)\end{array}$ & $\begin{array}{c}\text { Number of roots } \\
\text { per bulblet }\end{array}$ & $\begin{array}{c}\text { Root length } \\
(\mathrm{cm})\end{array}$ \\
\hline 0.0 & $56.25 \mathrm{~b}$ & $1.06 \mathrm{c}$ & $3.67 \mathrm{a}$ \\
0.49 & $56.25 \mathrm{~b}$ & $1.60 \mathrm{ab}$ & $2.87 \mathrm{~b}$ \\
0.98 & $93.75 \mathrm{a}$ & $1.75 \mathrm{ab}$ & $2.45 \mathrm{c}$ \\
1.96 & $81.25 \mathrm{ab}$ & $2.00 \mathrm{a}$ & $1.87 \mathrm{~d}$ \\
3.93 & $68.75 \mathrm{ab}$ & $1.37 \mathrm{bc}$ & $1.17 \mathrm{e}$ \\
7.8 & $62.50 \mathrm{~b}$ & $1.05 \mathrm{c}$ & $0.55 \mathrm{f}$ \\
MSD (P $\leq 0.05)$ & 28.86 & 0.40 & 0.36 \\
\hline \multicolumn{2}{l}{ Means in a column with same letter are not statistically different (Tukey, 0.05); MSD = minimum significant difference; $\mathrm{n}=9$ bulbs. }
\end{tabular}




\section{CONCLUSIONS}

The best BA concentration for shoot multiplication (20 $\mu \mathrm{M})$ allowed for a greater number of bulblets with shoots and shoots per bulblet obtained in shoot. Bulblet growth was improved by an increase in sucrose concentration up to $5 \%$ in the culture media, so this dose produced the best response. Taking into consideration the percentage of root formation, roots per bulblet and root length, the best IBA concentration for rooting was $0.98 \mu \mathrm{M}$. This protocol for micropropagation of Sprekelia formosissima allows to obtain at least 96 bulblets from each mother bulb in six months, surpassing by far the number of offspring that can be obtained under natural conditions, 1-2 bulb per year.

\section{ACKNOWLEDGEMENTS}

To the support of Sistema Nacional de Investigadores (Exp. 34643), and to Programa Integral de Fortalecimiento Institucional 3.2 and Programa de Mejoramiento del Profesorado for the financial support provided through the Agricultural Production Academic Body, UAEMORCA-74.

\section{BIBLIOGRAPHY}

Acosta E M, J Sánchez B, M Bañon A (2000) Auxinas. In: Fundamentos de Fisiologia Vegetal. J Azcón-Bieto, M Talón (coords). Mc Graw Hill. México. pp:305-323.

Ault J R (1995) In vitro propagation of Eucomis autumnalis, E. comosa, and E. zambesiaca by twin-scaling. HortScience 30:1441-1442.

Chaudhuri D, S Sen (2002) In vitro response of Scilla siberica. Sci. Hort. 95:51-62.

Chimal H A, V Corona N (2003) Arbustos mexicanos con potencial ornamental. In: Plantas Nativas de México con Potencial Ornamental, Análisis y Perspectivas. J M Mejía M, A Espinosa F (Comps.). Universidad Autónoma Chapingo. México. pp:31-51.

García E (1988) Modificaciones al Sistema de Clasificación Climática de Köppen (para adaptarlo a las condiciones de la Republica Mexicana). 4a ed. Universidad Nacional Autónoma de México. México. 246 p.
Grootaarts H, J H N Shel, R L M Pierik (1981) The origin of bulblets formed on excised twin scales of Nerine bowdenii W. Watts. Plant Cell Tiss. Org. Cult. 1:36-49.

Hartmann T H, E D Kester, F T Davies Jr (1990) Plant propagation principles and practices. 5a ed. Prentice-Hall. New Jersey. 647 p.

Leszczyñska-Borys H, W M Borys, S J L Galvan (1995) Relaciones raíz/bulbo y otras características de la Sprekelia (Sprekelia formosissima (L.) Herbert.). Rev. Chapingo S. Hort. 1:77-84.

Leszczyñska-Borys H, W M Borys (2000) Seed production of Sprekelia formisissima (L.) Herbert. Proc. Interam. Soc. Trop. Hort. 42:96-103.

Leszczyñska-Borys H, W M Borys (2001) Plantas Bulbosas para Flor de Corte, Macetas, Jardines y Parques. SIZA, CONACYT, UPAEP, FUPPUE. México. $85 \mathrm{p}$.

López-Ferrari A R, A Espejo-Serna (2002) Amaryllidaceae. In: Flora de Veracruz. V Sosa, L C Rodríguez, T Duncan, M T MejíaSaulés, N P Moreno, M Nee, L I Nevling, J Rzedowski J, B G Schubert (eds). Instituto de Ecología. Xalapa, Veracruz, México. 32 $\mathrm{p}$.

Mohamed-Yasseen Y (2002) In vitro micropropagation of spider lily (Hymenocallis speciosa L.). Arab Univ. J. Agric. Sci. 10:311318.

Murashige T, F Skoog (1962) A revised medium for rapid growth and bioassays with tobacco tissue cultures. Physiol. Plant. 15:473497.

Pierik R L M (1987) In Vitro Culture of Higher Plants. Martinus Nijhoff Publishers. Netherlands. $344 \mathrm{p}$.

Sánchez S O (1979) La Flora del Valle de México. Ed. Herrero. México, D. F. 103 p.

Santos A, F Fidalgo, I Santos, R Salema (2002) In vitro bulb formation of Narcissus asturiensis, a threatened species of Amaryllidaceae. J. Hort. Sci. Biotechnol. 77:149-152.

SAS (1998) SAS User's Guide: Statistics. Version 6.12. SAS Institute, Cary, N.C. $1848 \mathrm{p}$.

Segura J (2000) Citoquininas In: Fundamentos de Fisiologia Vegetal. J Azcón-Bieto, M Talón (coords). Mc Graw Hill. México. pp:343-360.

Tipirdamaz R (2003) Rooting and acclimatization of in vitro micropropagated snowdrop (Galanthus ikariae Baker) bulblets. Akdeniz Üniv. Ziraat Fak. Dergisi 16:121-126.

Van Dijk H, M Kupershoek (2003) La Enciclopedia de las Plantas Bulbosas. Ed. Libsa. Madrid. 336 p.

Ziv M, Lilien-Kipnis H (1997) The inflorescence stalk: A source of highly regenerative explants for micropropagation of geophytes. Acta Hort. 447:107-112. 